\title{
Organic micropollutants on river sediments from Rio de Janeiro State, Southeast Brazil
}

\author{
Micro-poluentes orgânicos em sedimentos fluviais \\ no Estado do Rio de Janeiro, Sudeste do Brasil
}

João Paulo Machado Torres ${ }^{1}$

Olaf Malm 1

Elisa Diniz Reis Vieira 1

Jan Japenga 2

Gerwin Ferdinand Koopmans 2

\footnotetext{
1 Laboratório de Radioisótopos Eduardo Penna Franca, Instituto de Biofísica Carlos Chagas Filho, Centro de Ciências da Saúde, Universidade Federal do Rio de Janeiro. Cidade Universitária, Ilha do Fundão, Rio de Janeiro, $R J$ 21941-900, Brasil. jptorres@biof.ufrj.br 2 Department of Water and the Environment, ALTERRA - Green World Research. P. O. Box 47. 6700 AA Wageningen, The Netherlands.
}

\begin{abstract}
The paper is a contribution for the knowledge upon concentrations and fate of different kinds of organic micropollutants in Tropical River system from a very industrialized region in Brazil. The presented data was obtained during three years of an International Research Project between Brazilian and Dutch institutions. The sediments were sampled at the Paraiba do Sul-Guandu river watershed, the most important watercourse of Rio de Janeiro state, where up $90 \%$ of the population depends on its water for domestic uses. After extraction with non-polar solvents in a hot sohxlet device and clean up using chromatographic columns, three classes of organic micropollutants were analyzed: organochlorine insecticides (OCs), polychlorinated biphenyls (PCBs) and polynuclear aromatic hydrocarbons (PAHs). The organochlorines, including the PCBs were scarcely present in the collected samples probably reflecting the restrictions of use of this class of compounds in the Brazilian market. However, the PAHs levels were high at the vicinity of a huge steelworks located in the city of Volta Redonda. This contamination is probably due to the massive use of coal in the above-cited metallurgical plant.
\end{abstract}

Key words Polychlorinated Biphenyls; Organochlorine Insecticides; Polycyclic Aromatic Hydrocarbons; Sediments; Endocrine Disruptors

Resumo Este artigo pretende contribuir para o conhecimento sobre a concentração e destino de diferentes tipos de micro-poluentes num sistema fluvial tropical de uma região brasileira altamente industrializada. Os dados apresentados foram obtidos ao longo de três anos, como parte de um projeto de pesquisa internacional envolvendo instituições brasileiras e holandesas. As amostras de sedimentos foram obtidas da bacia hidrográfica Paraíba do Sul/Guandu, a mais importante hidrovia no Estado do Rio de Janeiro, onde 90\% da população depende dessa água para uso doméstico. Após extração com solventes não-polares num dispositivo sohxlet quente, e limpeza utilizando colunas cromatográficas, foram analisadas três classes de micro-poluentes orgânicos: inseticidas organoclorados (OCs), bifenis policlorados (PCBs) e outros hidrocarbonetos polinucleares (PAHs). Os organoclorados, inclusive os PCBs, estavam presentes em quantidades muito reduzidas nas amostras, provavelmente refletindo as restrições contra o uso dessa classe de compostos no mercado brasileiro. Entretanto, os PAHs mostravam níveis elevados ao redor de uma grande indústria siderúrgica na cidade de Volta Redonda. Tal contaminação deve-se, provavelmente, ao uso maciço de carvão nesta fábrica.

Palavras-chave Bifenilos Policlorados; Inseticidas Organoclorados; Hidrocarbonetos Policíclicos Aromáticos; Sedimentos; Desreguladores Endócrinos 


\section{Introduction}

The present work is a contribution of the joint research project on organic micropollutants initiated in 1994. The project had the financial support of the European Commission and was entitled Organic Micropollutants in Tropical River Systems: The Paraíba do Sul-Guandu River Case Study.

The first efforts towards the installation of a laboratory for sample preparation and for the chromatographic devices (GC-ECD for the organochlorines and HPLC for the polynuclear aromatic hydrocarbons) were completed in March of 1994 and 1995, respectively.

The project was designed in order to give to the Brazilian group the expertise for sampling and analyzing different kinds of organic contaminants that can reduce, directly or indirectly reduce environmental quality.

Since the middle 80 's, the organochlorine insecticide utilization has been severely restricted in Brazil. However, it is known that large stocks of these compounds exist on some farms, and probably they are still being sold around the country by non-registered sellers. Only DDT and $\gamma-\mathrm{HCH}$ can be used by the Health Authorities against vectors of tropical diseases like malaria, yellow fever, dengue fever and leishmaniasis, although since the end of 1993, the Health Ministry decided to discontinue any use of there compounds. Brazil had recently (May 2001) signed the International Treaty that will ban 12 POPs (persistent organic pollutants) from utilization and trade.

Some studies during the last decades showed that as in other parts of the world, as in Brazil, that organic micropollutant contamination, outside the Agricultural fields, is directly related to urbanization (Luchini, et al., 1981; Tomassi, 1985). There are also some examples of the use of radiotracers to study the fate of pesticides in Brazilian soils (Helene et al., 1981; O'Connor et al., 1991). These studies reinforced the importance of organic and moisture contents in governing sorption and volatilization of organochlorines under tropical conditions.

In the Agricultural area, sometimes the utilization of some cyclodienes, like endosulfan, is permitted, but only after special evaluation and inspection of the crop problem. Aldrin can be used against ants and termites in wood protection (Pinto, 1995).

Polychlorinated biphenyls (PCBs) can only be used in closed systems like electric transformers as a dielectric fluid. Although their release in to the environment are not frequent, accidents involving leakage and direct contam- ination of surface and groundwater, especially near electrical facilities and big smelters have occurred. In 1988, while trying to protect the electric transformers from a fire in the Thyssen Foundry, more than 200kg of ASKAREL (a mineral oil containing PCBs) was dumped in to the Paraíba do Sul River by factory workers (Coelho, 1990). All of the water treatment plants situated downstream from this place had to stop their pumps until the toxic wave has passed.

The polynuclear aromatic hydrocarbons are a class of compounds in which two or more benzene rings are attached to each other and are formed by the partial combustion of organic matter, like wood, fossil fuels, petroleum derivatives and coal. Some of them are highly mutagenic (Harvey, 1982). The carcinogenic potential of these molecules have them listed by the United States Environmental Protection Agency (EPA) as priority pollutants.

All of these substances together have some common characteristics. Their octanol/water partition coefficients are always very high, meaning that their aqueous solubility is very low (IEOPOPS, 1990). On the other hand, as their lipophilicity is very high, their concentrations are expected to build-up in animal tissues (IEOPOPS, 1990; Larsson \& Sodergren, 1987; Neff, 1984). These molecules, once present in the environment, can biomagnify along the food web. The general tendency of escaping from a given phase, expressed by the fugacity constants, plays a key role in the environmental transport of the organic micropollutants (Mackay \& Paterson, 1982). These pollutants are also known as POPs.

\section{Study area}

The Paraíba do Sul-Guandu River system is the unique source of potable water for more than 10 million people in the metropolitan area of Rio de Janeiro city. The chosen stretch of this watershed covers the most industrialized region of Rio de Janeiro State (Figure 1). Most of the factories are metallurgical plants, but there are also some chemical plants and food industries, among them one brewery plant and a soft drink factory.

The Paraíba do Sul receives also all of the untreated urban sewage from the cities it crosses. The landscape in the middle course of the river has some mountains and river rapids. It is not a sharp valley; but the natural floodplain is very narrow. Nowadays, because of several dams that were constructed for electrical generation, the river hardly goes out of its course 


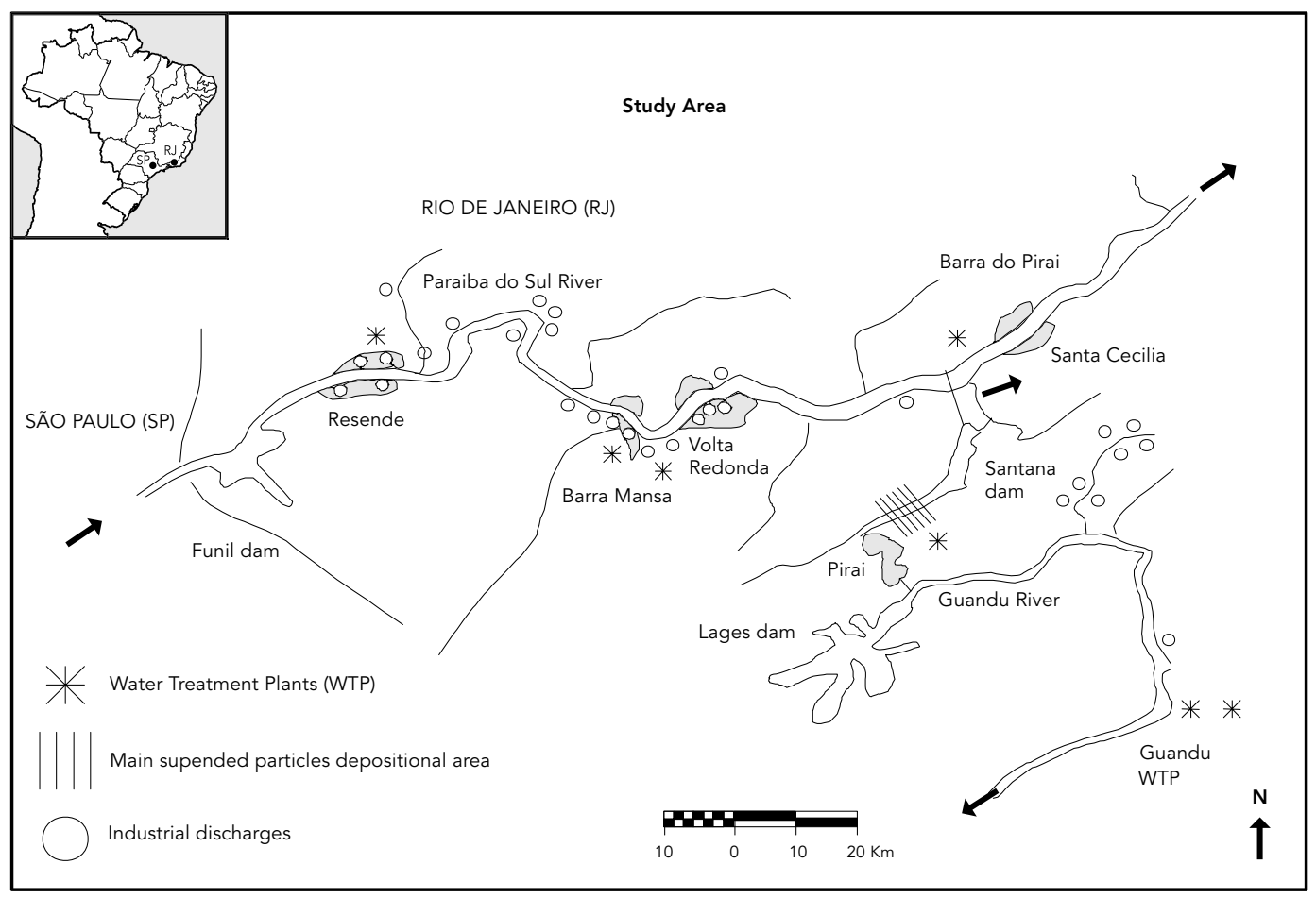

during the rainy season. At the end of this very industrialized region, $40 \%$ of the river water is pumped up to form reservoirs on the top of a mountain chain, named Santana and Vigario. After that, the water runs down to form the Guandu River, that will run to the second biggest Water Treatment Plant of the world, located in Santa Cruz, a district of the Rio de Janeiro municipality.

\section{Material and methods}

The river sediments were sampled using a metallic scoop, adapted at the end of a 4-meter long aluminum rod. They were stored in acetone washed glass jars, and kept at $4^{\circ} \mathrm{C}$ until analyzed. All the solvents have residue analysis quality, and the glassware was rinsed two times with analytical grade acetone prior analysis.

Basically, the analyzed pollutants have a non-polar character, which means that solvents with intermediate polarity can be used for the extraction step. The extraction procedure is the same for the three classes of pollutants: organochlorines, PCBs and PAHs (Japenga et al., 1987).
First, an aliquot of about $2 \mathrm{~g}$. of wet sediment is mixed with twice this quantity of wish hexane washed silica gel. In parallel, the water percentage and the organic content are determined gravimetrically after overnight analysis at $110^{\circ} \mathrm{C}$ and $550^{\circ} \mathrm{C}$, respectively.

The extractor is a modified hot sohxlet, which permits the continuous hot extraction for about two hours. The solvent used contains $25 \%$ of cycle-hexane in n-hexane, which make a low boiling point azeotropic mixture, that extract also the water from the sample. All pollutants are extracted using $20 \mathrm{ml}$ of this mixture and retained in $2 \mathrm{ml}$ of isooctane. Using a Kuderna-Danish device, the extract is concentrated to about $0,5 \mathrm{ml}$. When necessary, a gentle stream of $\mathrm{N}_{2}$ is used for concentration of the extracts before the fractionation.

During this process, other substances can be co-extracted, like elemental sulphur and humic substances. When present, they can severely interfere with the detection procedure.

The clean-up of the extracts is based on the Jensen reaction (Jensen et al., 1977). First a solution of $\mathrm{Na}_{2} \mathrm{SO}_{3}$ and $\mathrm{NaOH}$ is prepared and mixed with alkaline $\mathrm{Al}_{2} \mathrm{SO}_{4}$. The mixture is dried at $110^{\circ} \mathrm{C}$, down to the point were the ad- 
sorbent will contain $11 \%$ of water. This desulfurizating agent will quantitatively remove the elemental sulphur that is rather common, especially in anoxic sediments. The $0,5 \mathrm{ml}$ crude extract is transferred to the top of this desulfurizing agent. The elemental sulphur will react with the sulphide to form thiosulfate that will be retained along a wide bore glass column filled with 7 grams of the adsorbent. The elution of the column is done with $20 \mathrm{ml}$ of $\mathrm{n}$-hexane and the purified extract is diluted up to $50 \mathrm{ml}$ in acetone washed volumetric flasks.

Once purified, the $50 \mathrm{ml}$ extract is split, half in to organochlorinated hydrocarbons and half in to the polynuclear ones. The organochlorine portion of the extract is further fractionated to avoid overlapping of peaks in the gas-chromatogram.

The fractionation steps are done in open glass narrow bore columns filled with oven dried $\left(130{ }^{\circ} \mathrm{C}\right)$ silica gel. In one column the procedure for the fractionation of the OCs is done as follows:

- Fraction I: Twenty-five $\mathrm{ml}$ of the purified extract is allowed to evaporate in a KudernaDanish apparatus down to $0.5 \mathrm{ml}$. This volume is transferred to the top of the silica gel column and eluted with $15 \mathrm{ml}$ of $\mathrm{n}$-hexane. This fraction is evaporated down to $0.5 \mathrm{ml}$, and an internal standard for quantification is added $(0.5 \mathrm{ml}$ of a $200 \mathrm{ppb}$ of octachloronaphtalene-OCN). This fraction contains all of the PCBs and part of the organochlorines including HCB, Aldrin, Heptachlors and part of pp'-DDE to be analyzed in the CG-ECD. The concentration range of the standards is between 20 and $50 \mathrm{ng} / \mathrm{g}$.

- Fraction II: The same column is now eluted with $25 \mathrm{ml}$ of $\mathrm{n}$-hexane containing $10 \%$ of diethyl ether. Circa $0.5 \mathrm{ml}$ of isooctane is added to collect all of the pollutants and this mixture is evaporated in a Kuderna-Danish apparatus. To the remaining $0.5 \mathrm{ml}$, the same quantity of the internal standard OCN is added. This fraction will be analyzed for the remaining organochlorines in the CG-ECD (Lindane, Endosulfan, Dieldrin, Endrin, DDT and other metabolites). The concentration of these pesticides in the standard solution is between 20 and $40 \mathrm{ng} / \mathrm{g}$.

- Fraction III: Using another silica gel identically filled as the former ones, the third fraction will be collected. First, the remaining $25 \mathrm{ml}$ of the purified extract is allowed to concentrate in a Kuderna-Danish device down to $0.5 \mathrm{ml}$. This volume is transferred to the top of the column. First the column is eluted with $7 \mathrm{ml}$ of $\mathrm{n}$-hexane. This elluent is discarded. Using $35 \mathrm{ml}$ of $n-$ hexane/diethyl ether (9:1) the column is eluted. One $\mathrm{ml}$ of acetonitrile and $0.5 \mathrm{ml}$ of an in- ternal standard are added (Benzo[b]chrysene $2 \mathrm{mg} / \mathrm{l})$. Using the Kuderna-Danish, the extract is evaporated down to $1 \mathrm{ml}$ and is ready to be analyzed for PAHs in the HPLC-UV (Phenantrene, Anthracene, Fluoranthene, Pyrene, Chrysene, Benzo[a] anthracene, Benzo[b]fluoranthene, Benzo[k]fluoranthene, Benzo[a]pyrene, Dibenzo[ah] anthracene, Indeno[123-cd]pyrene, Benzo[ghi]perylene.

\section{Chromatographic equipments and conditions}

- Gas chromatograph: Shimadzu GC-14B, with auto-sampler AOC-1400. Columns: CBP-1 (SE-30) and CBP-5 (SE-52/54 confirmatory column). Injection: Splitless (30seg.) 300॰C. Temperature program of the oven: $110^{\circ} \mathrm{C}(1 \mathrm{~min}$.$) ;$ $15^{\circ} \mathrm{C} / \mathrm{min}$ up $170^{\circ} \mathrm{C} ; 7.5^{\circ} \mathrm{C} / \mathrm{min}$ up to $290^{\circ} \mathrm{C}$, hold for 10 minutes. Total run time: $25 \mathrm{~min}$ utes. Electron Capture Detector $(63 \mathrm{Ni})$ temperature: $310^{\circ} \mathrm{C}$.

- HPLC: Pump: Shimadzu LC-10AS; Mobile phase: acetonitrile: water $80 \%$, isocratic run. Column: Shimadzu STR-ODS-II (C-18 reverse phase) $25 \mathrm{~cm}$, L: $4 \mathrm{~mm}$ ID. UV/VIS detector model: Shimadzu SPD-10A

- Quality Control: For OC measurements, a certified reference material obtained from the International Atomic Energy Agency (IAEA 466) was used in order to calculate the recoveries of the method. The results found were within the acceptable range of concentrations for the certified sample. Together with every batch of 4 samples, an analytical reagent blank was inserted. Fortified samples were also extracted two times during the whole procedure. For PAHs, all of the analytical standards were used in two levels of concentrations, 50ng/g and $250 \mathrm{ng} / \mathrm{g}$ respectively.

All of the reported values express a dry weight basis. The organochlorinated pesticides and PCBs concentrations were normalized to $10 \%$ of organic matter, determined gravimetrically (450॰C, overnight). All of the PAH values were also corrected to the analytical recovery of tests using two PAH contaminated reference materials obtained from RIZA, The Netherlands. The average recovery of these tests $(\mathrm{N}=$ 6) was around $60-70 \%$.

Also regarding analytical quality control of the PAH levels, a series of analysis was performed at the Winand Staring Centre, Wageningen, The Netherlands. In this set of data the correction was not performed. In the recovery test, done with the RIZA certified material, a general recovery of $90 \%$ was achieved. Their 
methodology is based on acetone: petroleum ether extraction followed by HPLC with on-line C-8 solid phase clean-up and fluorescence detection.

\section{Results and discussion}

Fourteen sampling points were established in the Paraiba do Sul River. Sediments were sampled and analyzed between 1994 and 1996. At ten stations, organic micropollutants were present. The other samples where sandy ones, collected between Itatiaia and Barra Mansa, upstream the most industrialized upstream stretch of the river.

In the same period, in the other 14 stations, sediment samples were collected at the Guandu River basin. As most stations have coarse sandy sediment, the presence of organochlorines was hardly identified. The PAHs presence, though very low, was observed in half of the samples.
As referred above, organochlorinated hydrocarbons, including PCBs were detected sparsely on the collected surface sediments. For example, no OC residues could be found at Itatiaia or Porto Real. After Volta Redonda, a relative low contamination with $\mathrm{PCBs}$ could be detected $(\Sigma$ of PCBs $=19 \mathrm{ng} / \mathrm{g})$. The relative contribution of the lower chlorinated congeners is evident, especially at Pinheiral ( $\Sigma$ of PCBs $=67 \mathrm{ng} / \mathrm{g})$.

Among DDT and its metabolites, o,p'-DDT and p,p'-DDE, were present between Volta Redonda (densely populated) and Barra do Pirai. The $\Sigma$ of DDTs near Volta Redonda is around $225 \mathrm{ng} / \mathrm{g}$. Traces of HCB near the first town were below 5ng/g, while near Barra do Piraí this level was 5 times greater (25ng/g). At Volta Redonda the presence of the cyclodienes heptachlorepoxide and aldrin were detected in low levels (5-20ng/g).

The results are shown in Table 1.

The analysis of PAHs at the PSR present a different pattern was observed. The levels be-

Organichlorines on sediments from the Paraíba do Sul River (ng/g).

\begin{tabular}{|c|c|c|c|c|c|c|c|c|c|}
\hline & \multicolumn{3}{|c|}{ Volta Redonda } & \multicolumn{3}{|c|}{ Pinheiral } & \multirow{2}{*}{$\begin{array}{l}\text { Vargem } \\
\text { Alegre }\end{array}$} & \multirow{2}{*}{$\begin{array}{c}\text { BR-393, } \\
\text { Km } 25\end{array}$} & \multirow{2}{*}{$\begin{array}{c}\text { Piraí } \\
\text { Santana } \\
\text { reservoir }\end{array}$} \\
\hline & R. Bolívia & $\begin{array}{c}\text { Santo } \\
\text { Agostinho }\end{array}$ & $\begin{array}{c}\text { Pt. } \\
\text { Cajueiro }\end{array}$ & Olaria & Areal & WTP & & & \\
\hline PCB-28 & & & & 14.7 & 8.0 & & 3.0 & 18.9 & 3.3 \\
\hline PCB-52 & 0.6 & & & 15.4 & 4.1 & 13.2 & & & 3.8 \\
\hline PCB-101 & 0.1 & & & 6.4 & 2.8 & 1.3 & & 9.6 & 0.9 \\
\hline PCB-118 & & 2.4 & & 7.2 & 4.2 & & 0.8 & & 2.3 \\
\hline PCB-153 & 0.3 & 6.1 & & 10.4 & 6.4 & 6.8 & 1.0 & & 3.8 \\
\hline PCB-138 & & 6.4 & & 8.9 & 5.8 & 4.9 & 1.1 & & 3.3 \\
\hline PCB-180 & & 4.5 & & 4.5 & 3.2 & 2.7 & 0.7 & & 2.2 \\
\hline Total & 1.0 & 19.3 & & 67.5 & 34.5 & 29.0 & 6.5 & 28.6 & 19.5 \\
\hline$p, p^{\prime}-D D E$ & 0.2 & 2.4 & 4.0 & 20.5 & 9.6 & 5.9 & & & \\
\hline $0, p^{\prime}-D D E$ & & & & 4.4 & 1.8 & & & 0.8 & 1.2 \\
\hline \multicolumn{10}{|l|}{$p, p^{\prime}-D D D$} \\
\hline \multicolumn{10}{|l|}{$0, p^{\prime}-D D T$} \\
\hline$p, p^{\prime}-D D T$ & 48.0 & 214.5 & 56.2 & 31.9 & 15.7 & 18.9 & & & \\
\hline Total & 48.2 & 216.9 & 60.2 & 56.8 & 27.1 & 24.8 & & 0.8 & 1.2 \\
\hline $\mathrm{HCB}$ & & & & 3.4 & 2.2 & 5.3 & 0.4 & 27.7 & 1.7 \\
\hline \multicolumn{10}{|l|}{$\gamma-\mathrm{HCH}$} \\
\hline Heptachlor & 0.1 & & & & & & & & \\
\hline Heptachlorepoxide & & & & 4.0 & 3.8 & & & & 1.3 \\
\hline \multicolumn{10}{|l|}{$\alpha$-Endosulfan } \\
\hline Aldrin & 0.2 & & & & & & & & \\
\hline Dieldrin & & & & 21.2 & 13.0 & 12.9 & 0.2 & & \\
\hline Endrin & & & & & & & & & \\
\hline
\end{tabular}

Blank values are under detection limits; $3 x$ baseline noise.

WTP $=$ Water Treatment Plant. 
fore and near Barra Mansa were low ( $\Sigma$ of 12 PAHs $<1 \mathrm{mg} / \mathrm{kg}$ ). At Volta Redonda, however, the PAHs values can be more than 40 times greater ( $\Sigma$ of 12 PAHs $>40 \mathrm{mg} / \mathrm{kg}$ ), indicating the presence of an important source in this city. Volta Redonda owns the largest steelworks in Latin America, the Companhia Siderúrgica Nacional (CSN).

As the river runs towards Barra do Pirai the contamination decreases, but the relative contribution of each of the analysed PAHs remains more or less the same (Table 2, Figure 2), indicating the presence of an important source in the area.

The relation between Benzo[a]pyrene (b[a]p) and Phenanthrene (phe) concentrations most of the time is less than one. Only at Santo Agostinho, a station very close to the refuse site of the steelworks, and at the Santana Reservoir, an important sedimentation area, is the relationship at 1:2. Large amounts of coal have been used since the beginning of the operation of the CSN plant in 1942. Coal combustion generates a complex mixture of PAHs, particularly rich in heavier PAHs (Edwards, 1983).

The B[a]P/Phe index from the SC-DLO data shows most stations with $>1$ values. The different extraction procedure and analysis may explain this fact. More ringed PAHs are better seen with fluorescence detection.

As a matter of fact the two data sets will gender the same conclusion. After emission, heav- ier PAHs adsorbed to the suspended particles that eventually will become part of the bottom sediment, especially at sedimentation areas. Generally speaking, sediment can be viewed as a sink or as a source of organic micropollutants. Some of the PAHs associated with dissolved organic matter may remain in the solution (Malm \& Bril, 1997).

With this in mind, the presence of highly mutagenic molecules in relatively high amounts in rivers used for water supply of the huge metropolitan area of Rio de Janeiro is a matter of great concern. The purity of the water will be directly related to the efficiency of the treatment plants to reduce drastically the dissolved organic carbon and get rid of suspended particles (Azcue et al. 1987).

Tomassi (1985) presented the first Brazilian survey on organochlorine levels in an urban coastal estuary in São Paulo State. These OC results are in the same range as the ones presented here. For example, our highest DDT value, $210 \mathrm{ppb}$, is similar to Tomassi's highest result, $300 \mathrm{ppb}$. However, on lacustrine sediments from a freshwater reservoir (Lobo-Broa, São Paulo), the highest reported value of DDT was < 8ppb (Celeste \& Cáceres, 1988).

Residue analysis of environmental samples was also conducted near important agricultural areas from Paraná State in Brazil. They found that in $43 \%$ of the samples HCB could be detected. In $38 \%$ Aldrin was found and Heptachlor

PAH on sediments from the Paraíba do Sul River (ng/g).

\begin{tabular}{|c|c|c|c|c|c|c|c|c|c|c|}
\hline & \multicolumn{4}{|c|}{ Volta Redonda } & \multicolumn{3}{|c|}{ Pinheiral } & \multirow{2}{*}{$\begin{array}{l}\text { Vargem } \\
\text { Alegre }\end{array}$} & \multirow{2}{*}{$\begin{array}{l}\text { BR-393, } \\
\text { Km } 25\end{array}$} & \multirow{2}{*}{$\begin{array}{c}\text { Piraí } \\
\text { Santana } \\
\text { reservoir }\end{array}$} \\
\hline & CSN 1 & R. Bolívia & $\begin{array}{c}\text { Santo } \\
\text { Agostinho }\end{array}$ & $\begin{array}{c}\text { Pt. } \\
\text { Cajueiro }\end{array}$ & Olaria & Areal & WTP & & & \\
\hline Phenanthrene & 1,213 & 1,379 & 2,058 & 5,377 & 1,631 & 1,225 & 655 & 1,440 & 1,713 & 516 \\
\hline Anthracene & 282 & 543 & 983 & 1,967 & 681 & 452 & 219 & 537 & 759 & 206 \\
\hline Fluoranthene & 1,105 & 2,614 & 8,564 & 9,264 & 3,211 & 2,029 & 1,359 & 2,492 & 4,163 & 1,600 \\
\hline Pyrene & 942 & 1,650 & 5,453 & 6,341 & 2,290 & 1,416 & 951 & 1,547 & 2,601 & 1,096 \\
\hline Chrysene & 266 & 1,233 & 5,283 & 3,869 & 1,446 & 865 & 637 & 990 & 2,021 & 968 \\
\hline Benzo[a]anthracene & 297 & 1,210 & 5,244 & 3,780 & 1,427 & 858 & 628 & 984 & 1,969 & 946 \\
\hline Benzo[b]fluoranthene & 303 & 824 & 3,599 & 2,705 & 1,178 & 667 & 475 & 676 & 1,458 & 873 \\
\hline Benzo[k]fluoranthene & 127 & 415 & 1,813 & 1,434 & 591 & 342 & 248 & 332 & 693 & 434 \\
\hline Benzo[a]pyrene & 206 & 642 & 3,362 & 2,579 & 871 & 454 & 422 & 606 & 1,348 & 810 \\
\hline Dibenzo[ah]anthracene & 235 & 11 & 62 & 19 & 6 & 5 & 3 & 7 & 15 & 8 \\
\hline Indeno[123cd]pyrene & 137 & 560 & 2,742 & 1,412 & 685 & 371 & 246 & 422 & 873 & 558 \\
\hline Benzo[ghi]perylene & NA & 339 & 1,610 & 1,016 & 445 & 256 & 90 & 273 & 578 & 369 \\
\hline $\mathrm{B}[\mathrm{a}] \mathrm{P} / \mathrm{Phe}$ & 0.2 & 0.5 & 1.6 & 0.5 & 0.5 & 0.4 & 0.6 & 0.4 & 0.8 & 1.6 \\
\hline Sum of PAHs & 5,113 & 11,418 & 40,773 & 39,762 & 14,461 & 8,940 & 5,932 & 10,305 & 18,190 & 8,384 \\
\hline
\end{tabular}

$\mathrm{CSN}=$ Companhia Siderúrgica Nacional; WTP = Water Treatment Plant. 
Figure 2

PAHs on sediments from the Paraíba do Sul River, 1994-1996.

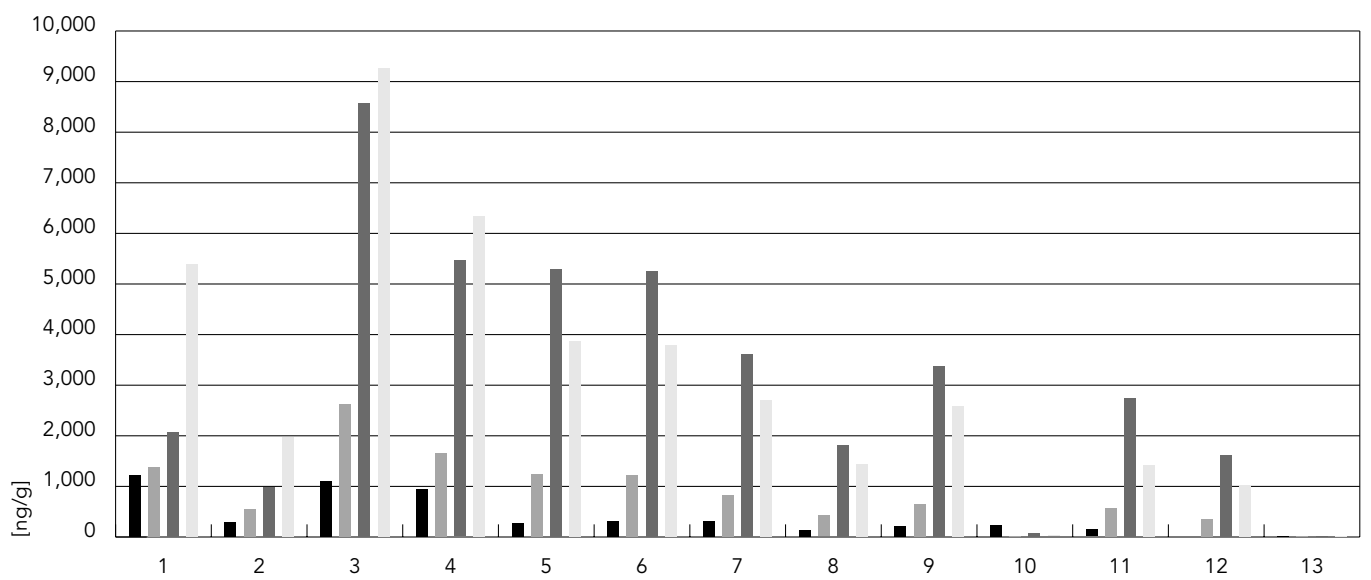

CSN 1

(Volta Redonda)

R. Bolívia

(Volta Redonda)

Santo Agostinho

(Volta Redonda)

Pt. Cajueiro

(Volta Redonda)

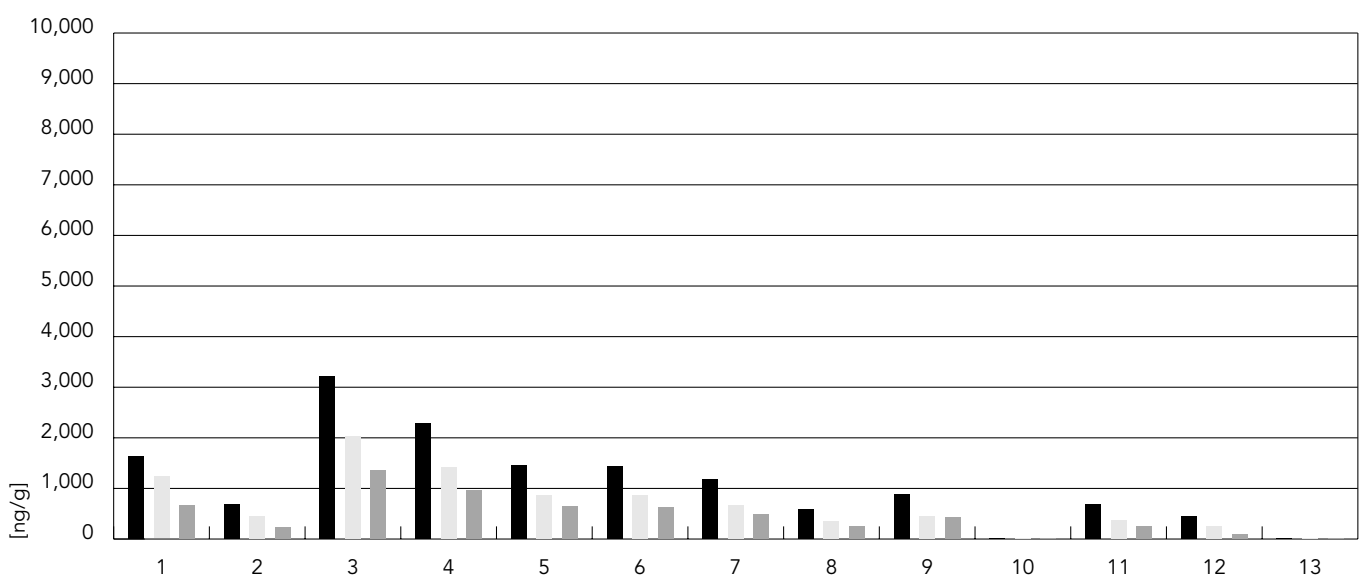

Olaria (Pinheiral)

Areal (Pinheiral)

WTP (Pinheiral)

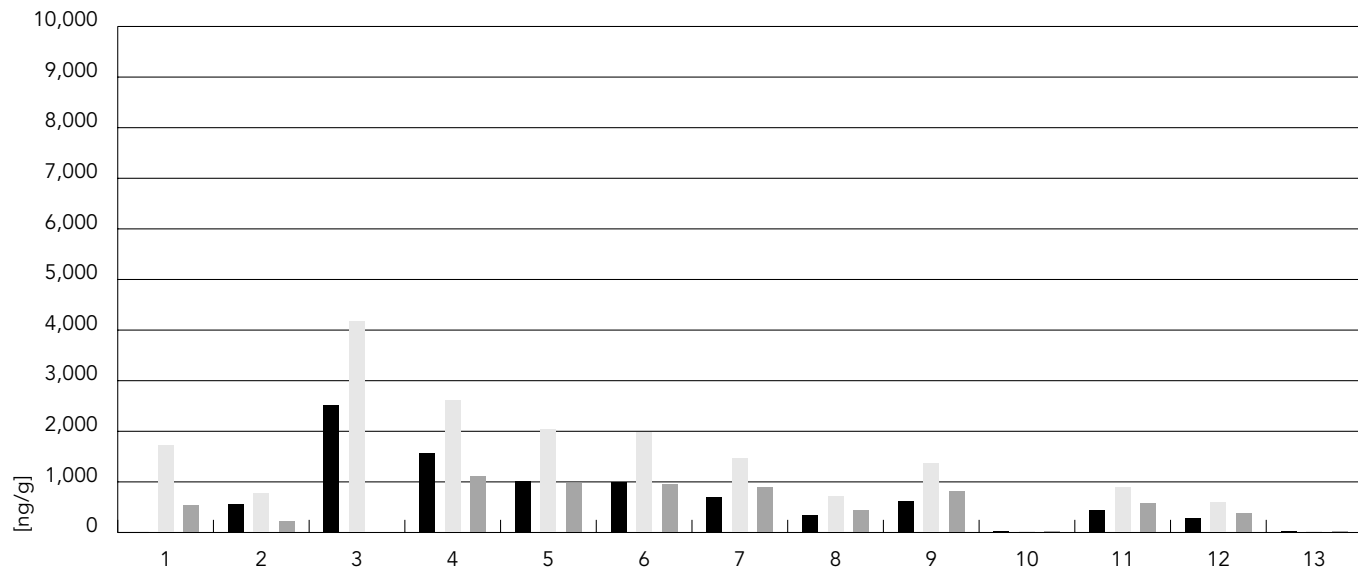

Vargem Alegre

BR-393, Km 25

Santana

reservoir (Piraí)

1 = Phenanthrene; 2 = Anthracene; 3 = Fluoranthene; 4 = Pyrene; 5 = Chrysene; 6 = Benzo[a]anthracene

7 = Benzo[b]fluoranthene; 8 = Benzo[k]fluoranthene; 9 = Benzo[a]pyrene; 10 = Dibenzo[ah]anthracene

11 = Indeno[123cd]pyrene; 12 = Benzo[ghi]perylene; 13 = B[a]P/Phe.

$\mathrm{CSN}=$ Companhia Siderúrgica Nacional; WTP = Water Treatment Plant. 
residues were present in $18 \%$ of the samples (Tanamati et al., 1991). In water samples, other authors have found low levels in the Paraná and São Paulo State watercourses (Cáceres et al., 1988; Souza et al., 1988).

Twenty years ago, a report from CETESB, the Environmental Agency of Sao Paulo State (Southeast Brazil), presented concentrations of some organochlorines on bottom sediments from the PSR basin, upstream from the Funil Dam that were 1,000 times higher than the ones found in this work (CETESB, 1978). Ten years after, this contamination virtually disappeared and no PCBs or organochlorine residues were present on sediments collected in the Fu- nil dam near the border between São Paulo and Rio de Janeiro states (Coelho \& Fonseca, 1988).

In our study, the last agriculture area is now being industrialized. This helps to explain the low levels of organochlorine insecticides found. The presence of PCBs (Figure 3 ) is more marked, reflecting the urbanization and industrial development of the Paraíba do Sul River Valley (PASIN, 1988).

Japenga and co-workers reported in 1988 sediment concentrations of organic micropollutants in the Rio de Janeiro coastal area (Japenga et al., 1988). Their OC and PAH values are within the same order of magnitude of the ones reported here. The same can be said about

Figure 3

PCBs on sediments from the Paraíba do Sul River.

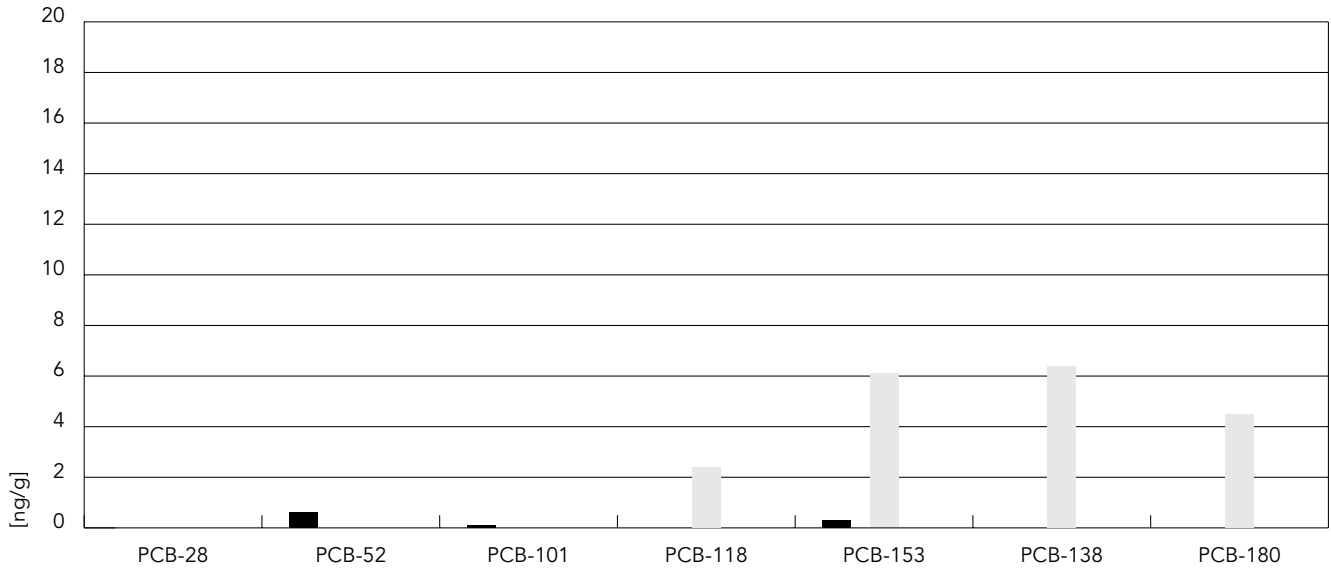

R. Bolívia

(Volta Redonda)

Santo Agostinho (Volta Redonda)

Pt. Cajueiro

(Volta Redonda)

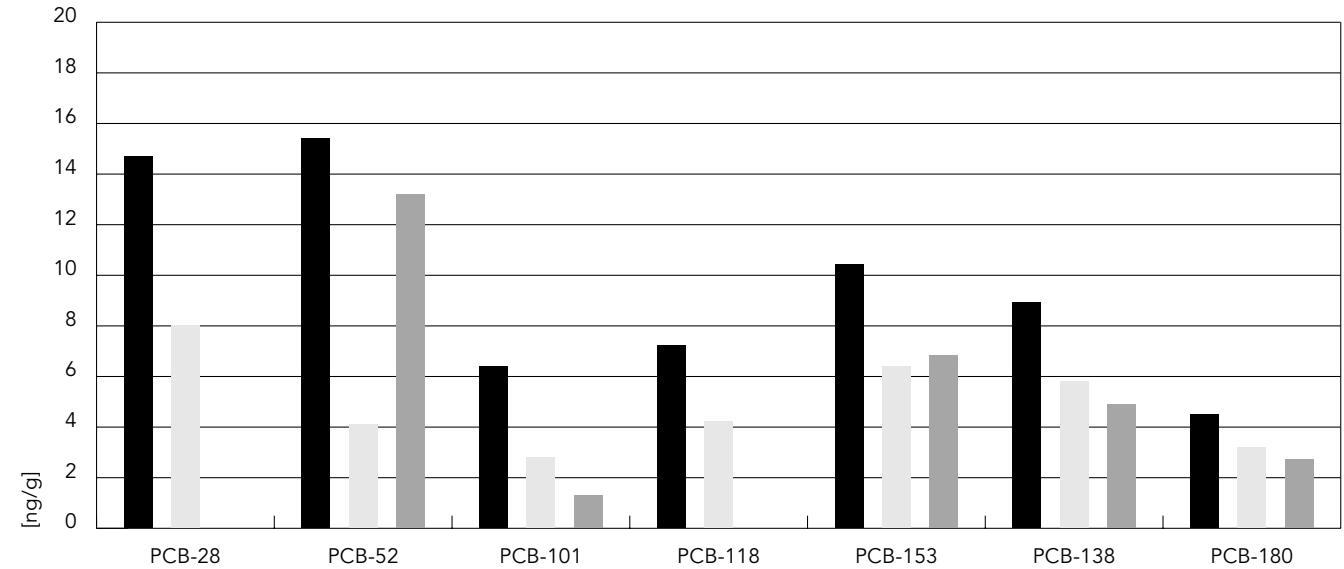

Olaria (Pinheiral)

Areal (Pinheiral)

WTP (Pinheiral)

(to be continued on next page) 
the ones reported by Lima working with core samples from the Guanabara Bay, close to Rio de Janeiro city in 1996 (Sum of PAHs < 20mg/kg) (Lima, 1996).

In Table 3, PAH results obtained at the Winand Staring Centre, The Netherlands, by fluorescence detection after the extraction ac- cording to Dutch protocols confirm the same pattern of anthropogenic PAH contamination (Figure 4). The relative contribution of specific PAHs is quite similar in both data sets.

Although the Guandu River receives most of its waters from the PSR, the presence of organic micropollutants is notably diverse, and

Figure 3 (continued from previous page)

PCBs on sediments from the Paraíba do Sul River.

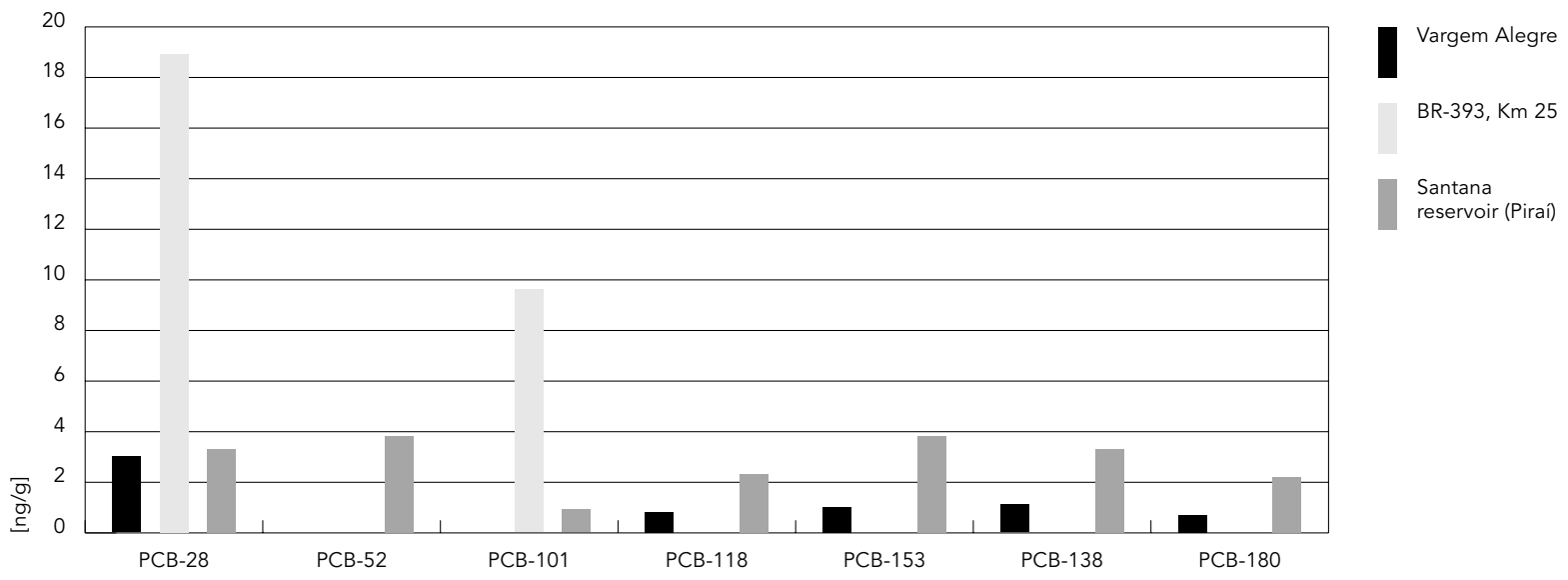

Table 3

$\mathrm{PAH}$ on sediments from the Paraíba do Sul River (ng/g), analyzed at the SC-DLO.

\begin{tabular}{|c|c|c|c|c|c|c|c|c|}
\hline & \multirow[t]{2}{*}{ Barra Mansa } & \multicolumn{4}{|c|}{ Volta Redonda } & \multirow{2}{*}{$\begin{array}{l}\text { Pinheiral } \\
\text { WTP }\end{array}$} & \multirow{2}{*}{$\begin{array}{c}\text { Barra do Piraí } \\
\text { WTP }\end{array}$} & \multirow{2}{*}{$\begin{array}{c}\text { Piraí } \\
\text { Santana } \\
\text { reservoir }\end{array}$} \\
\hline & & CSN 1 & R. Bolívia & $\begin{array}{c}\text { Santo } \\
\text { Agostinho }\end{array}$ & $\begin{array}{c}\text { Pt. } \\
\text { Cajueiro }\end{array}$ & & & \\
\hline Phenanthrene & 72 & 2,284 & 885 & 702 & 382 & 948 & 696 & 1,277 \\
\hline Anthracene & 8 & 583 & 212 & 156 & 90 & 250 & 209 & 418 \\
\hline Fluoranthene & 47 & 2,875 & 1,189 & 1,190 & 627 & 1,432 & 1,354 & 2,545 \\
\hline Pyrene & 53 & 2,449 & 1,091 & 1,161 & 616 & 1,337 & 1,098 & 2,287 \\
\hline Chrysene & 37 & 1,632 & 630 & 740 & 427 & 958 & 758 & 1,779 \\
\hline Benzo[a]anthracene & 47 & 1,807 & 634 & 835 & 465 & 943 & 719 & 1,775 \\
\hline Benzo[b]fluoranthene & 64 & 1,589 & 555 & 808 & 442 & 1,001 & 710 & 1,820 \\
\hline Benzo[k]fluoranthene & 22 & 755 & 276 & 381 & 211 & 499 & 341 & 953 \\
\hline Benzo[a]pyrene & 43 & 1,543 & 612 & 789 & 451 & 1,053 & 717 & 1,991 \\
\hline Dibenzo[ah]anthracene & 6 & 218 & 97 & 124 & 73 & 183 & 119 & 354 \\
\hline Indeno[123cd]pyrene & 80 & 1,524 & 407 & 583 & 312 & 652 & 422 & 1,240 \\
\hline Benzo[ghi]perylene & 53 & 1,408 & 510 & 710 & 393 & 912 & 567 & 1,641 \\
\hline $\mathrm{B}[\mathrm{a}] \mathrm{P} / \mathrm{Phe}$ & 0.6 & 0.7 & 0.7 & 1.1 & 1.2 & 1.1 & 1.0 & 1.6 \\
\hline Sum of PAHs & 532 & 18,667 & 7,098 & 8,179 & 4,489 & 10,168 & 7,710 & 18,080 \\
\hline
\end{tabular}

CSN = Companhia Siderúrgica Nacional; WTP = Water Treatment Plant. 
Figure 4

PAHs on Paraíba do Sul River sediments (SC-DLO data).

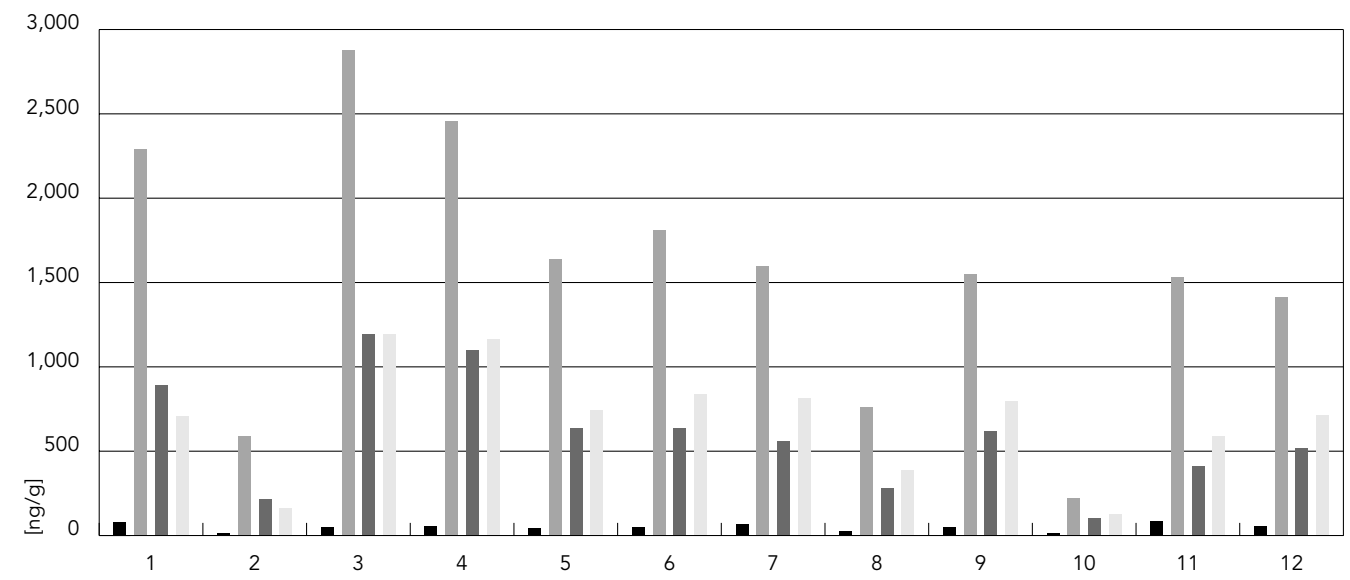

Barra Mansa

CSN 1

(Volta Redonda)

R. Bolívia

(Volta Redonda)

Santo Agostinho

(Volta Redonda)

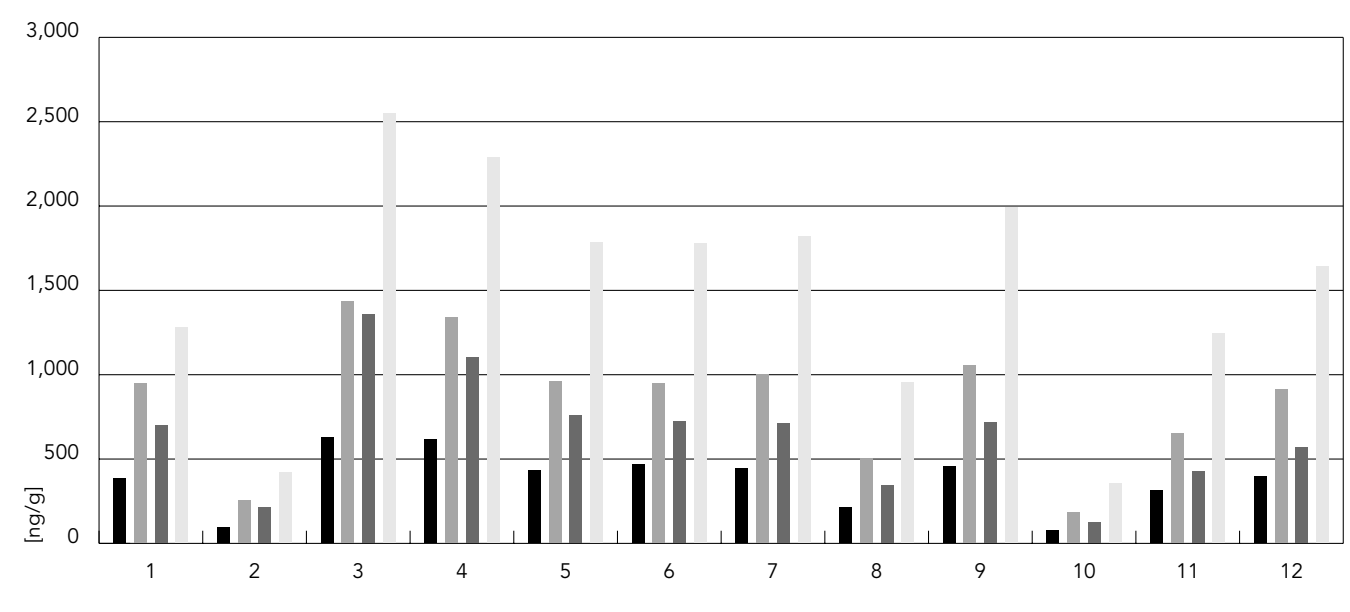

Pt. Cajueiro

(Volta Redonda)

WTP (Pinheiral)

WTP (Barra do Piraí)

Santana

reservoir (Piraí)

1 = Phenanthrene; $2=$ Anthracene; 3 = Fluoranthene; 4 = Pyrene; $5=$ Chrysene; 6 = Benzo[a]anthracene

7 = Benzo[b]fluoranthene; 8 = Benzo[k]fluoranthene; 9 = Benzo[a]pyrene; 10 = Dibenzo[ah]anthracene;

11 = Indeno[123cd]pyrene; 12 = Benzo[ghi]perylene.

only traces of chlorinated pesticides (HCB) or PAHs are present in some tributaries. The PAH level of this area is presented in at Table 4. The Queimados River crosses an industrial district with the same name. In the past, another Steelwork Company was installed in this place. The $\mathrm{B}[\mathrm{a}] \mathrm{P} / \mathrm{Phe}$ index in this station is around 2. Only the less chlorinated PCBs (PCB-28 and 52) were present on the bottom sediments from the Guandu River.

\section{Conclusions}

This work represents the first survey of POPs concentrations at the most important source of water for more than 10 million people that live in the Rio de Janeiro Metropolitan Area. The results presented here are indicates that industrial contaminants, mainly PAHs are reaching important reservoirs that are used for water consumption and this fact deserves closer investigation and monitoring in order to protect human health. 
PAHs on sediments from the Guandu River basin (ng/g).

\begin{tabular}{|c|c|c|c|c|c|c|c|}
\hline & \multicolumn{2}{|c|}{ Poços River } & \multirow{2}{*}{$\begin{array}{l}\text { Queimados River } \\
\text { Industrial } \\
\text { District }\end{array}$} & \multicolumn{4}{|c|}{ Guandu River } \\
\hline & BR-116 & $\begin{array}{l}\text { Industrial } \\
\text { District }\end{array}$ & & Japeri & Paracambi & BR-116 & Santa Cruz \\
\hline Phenanthrene & 25 & 118 & 268 & 78 & 64 & 7 & \\
\hline Anthracene & 10 & 14 & 45 & 12 & 12 & 3 & \\
\hline Fluoranthene & 80 & 57 & 186 & 35 & 79 & 25 & \\
\hline Pyrene & 75 & & 3,101 & 627 & 101 & & \\
\hline Chrysene & & & 122 & & 28 & & 8 \\
\hline Benzo[a]anthracene & 52 & 41 & 369 & & 808 & & 8 \\
\hline Benzo[b]fluoranthene & & & 595 & & & 20 & \\
\hline Benzo[k]fluoranthene & 49 & 43 & 527 & 81 & 48 & & 7 \\
\hline Benzo[a]pyrene & 55 & & 560 & 20 & 46 & & \\
\hline Dibenzo[ah]anthracene & & & 1,175 & & & & \\
\hline Indeno[123cd]pyrene & 90 & & 498 & & & & \\
\hline Benzo[ghi]perylene & 43 & & 712 & & & & \\
\hline $\mathrm{B}[\mathrm{a}] \mathrm{P} / \mathrm{Phe}$ & 2.2 & 0.0 & 2.1 & 0.3 & 0.7 & & \\
\hline Sum of 12 PAHs & 478 & 272 & 8,156 & 853 & 1,186 & 55 & 15 \\
\hline
\end{tabular}

Blank values are under detection limits; $<3 x$ baseline noise.

\section{Acknowledgements}

This work received support from the Commission of the European Community (Project number: C11*CT93-0055), and Conselho Nacional de Desenvolvimento Científico e Tecnológico, Brazil (PRONEX 877). Nowadays, Dr. João Torres is a Selikoff Fellow at the Mount Sinai School of Medicine and Queens College at New York and his research is partially supported by the Grant 1 D43 TW00640 from the Fogarty International Center of the National Institutes of Health, United States.

\section{References}

AZCUE, J.; PFEIFFER, W. C.; FISZMAN, M. \& MALM, O., 1987. Heavy metals in drinking waters from the Paraiba do Sul - Guandu River system, Rio de Janeiro State, Brazil. Water Science and Technology, 19:1181-1183.

CÁCERES, O.; TUNDISI, J. G. \& CASTELLAN, O. A. M., 1988. Residues of organochloric pesticides in reservoirs of São Paulo State. Ciência e Cultura, 39:259-264.

CELESTE, M. F. \& CÁCERES, O., 1988. Resíduos de praguicidas organoclorados no sedimento da represa do Lobo (Broa) - São Carlos, SP. Ciência e Cultura, 40:900-905.

COELHO, V., 1990. O Acidente com Óleo Ascarel no Rio Paraiba do Sul. Relatório Técnico Feema 06/241. Rio de Janeiro: Fundação Estadual de Engenharia e Meio-Ambiente.

COELHO, V. M. B. \& FONSECA, M. R., 1988. Estudio de Caso: La Contaminación de las Águas del Rio Paraiba do Sul. Washington, DC: Pan American Health Organization.

EDWARDS, N. T., 1983. Polycyclic Aromatic Hydrocarbons (PAHs) in the terrestrial environment - A review. Journal of Environmental Quality, 12:427441. 
HARVEY, R. G., 1982. Polycyclic hydrocarbons and cancer. American Scientist, 70:386-393.

HELENE, C. G.; LORD, K. A. \& RUEGG, E. F., 1981. The persistence and volatilization of Aldrin- C-14 in two Brazilian soils. Ciência e Cultura, 33:101-105.

IEOPOPS (International Experts on POPs), 1990. Meeting Background Report. International Experts Meeting on Persistent Organic Pollutants: Towards Global Action. Ottawa: Ministry of Environment.

JAPENGA, J.; WAGENAAR, W. J.; SALOMONS, W.; LACERDA, L. D.; PATCHINEELAM, S. R. \& LEITÃO FILHO, C. M., 1988. Organic micropollutants in the Rio de Janeiro coastal areas in, Brazil. Science of the Total Environment. 75:249-259.

JAPENGA, J.; WAGENAAR, W. J.; SMEDES, F. \& SALOMONS, W., 1987. A new, rapid clean-up procedure for the simultaneous determination of different groups of organic micropollutants in sediments: Application in two estuarine sediment samples. Environmental Technology Letters, 8:920.

JENSEN, S.; RENBERG, L. \& REUTEGARDH, L., 1977. Residue analysis of sediment and sewage sludge for organochlorines in the presence of elemental sulfur. Analytical Chemistry, 49:316:318.

LARSSON, P. \& SODERGREN, A., 1987. Transport of polychlorinated biphenyls (PCBs) in Freshwater mesocosms from sediment to water and air. $\mathrm{Wa}$ ter, Air and Soil Pollution, 36:33-46.

LIMA, A. L. C., 1996. Geocronologia de Hidrocarbonetos Policíclicos Aromáticos. Estudo de Caso: Baía de Guanabara. Dissertação de Mestrado, Rio de Janeiro: Pontifícia Universidade Católica.

LUCHINI, L. C.; LORD, K. A. \& RUEGG, E. F., 1981. Sorption and desorption of pesticides on Brazilian soils. Ciência e Cultura, 33:97-101.

MACKAY, D. \& PATERSON, S., 1982. Fugacity revisited. Environmental Science and Technology, 16: 654a-660a.
MALM, O. \& BRIL, J., 1997. Developing of a simple river basin model for understanding the fate of organic micropollutants. In: International Workshop on Organic Micropollutants in the Environment, Abstracts, pp. 67-72. Rio de Janeiro: Instituto de Biofísica Carlos Chagas Filho, Universidade Federal do Rio de Janeiro.

NEFF, J. M., 1984. Bioaccumulation of organic micropollutants from sediments and suspended particles by aquatic animals. Freseniu's Journal of Analytical Chemistry, 319:132-136.

O'CONNOR, T. P. \& EHLER, C. N., 1991. Results from the NOAA National status and trends program on distribution and effects of chemical contamination in the coastal and estuarine United States. Environmental Monitoring and Assessment, 17: 33-49.

PASIN, J. L., 1988. O Vale do Paraíba - Ontem e Hoje. Rio de Janeiro: AC\&M/Monsanto do Brasil.

PINTO, W. D., 1995. Legislação Ambiental Brasileira. Brasília: Instituto Brasileiro do Meio Ambiente e dos Recursos Naturais Renováveis.

CETESB (Companhia de Tecnologia de Saneamento Ambiental), 1978. Campanha Especial de Metais Pesados e Pesticidas Realizada no Rio Paraíba do Sul. São Paulo: Superintendência de Tecnologia, Gerência de Avaliação da Qualidade das Águas, CETESB.

SOUZA, N. E.; RUBIRA, A. F.; MATSUSHITA, M. \& TANAMATI, A., 1988. Resíduos de pesticidas organoclorados em amostras ambientais (águas e solos) do Município de Maringá. Arquivos de Biologia e Tecnologia, 31:587-594.

TANAMATI, A.; RUBIRA, A. F.; MATSUSHITA, M. \& SOUZA, N. E., 1991. Resíduos de pesticidas organoclorados no rio Baía, afluente do rio Paraná, Região de Porto Rico - PR, Brasil. Arquivos de Biologia e Tecnologia, 34:303-315.

TOMASSI, L. R., 1985. Resíduos de praguicidas em águas e sedimentos de fundo do sistema estuarino de Santos (SP). Ciência e Cultura, 37:1001-1012.

Submitted on 29 March 2001

Final version resubmitted on 5 July 2001

Approved on 24 August 2001 